Variants

The Journal of the European Society for Textual

Scholarship

12-13 | 2016

Varia

\title{
Ivo Castro, Editar Pessoa
}

\section{Simone Celani}

OpenEdition

Electronic version

URL: http://journals.openedition.org/variants/391

DOI: 10.4000/variants.391

ISSN: 1879-6095

Publisher

European Society for Textual Scholarship

\section{Printed version}

Date of publication: 31 December 2016

Number of pages: 249-253

ISSN: 1573-3084

Electronic reference

Simone Celani, «Ivo Castro, Editar Pessoa», Variants [Online], 12-13 | 2016, Online since 01 May 2017 connection on 25 September 2020. URL : http://journals.openedition.org/variants/391 ; DOI : https:// doi.org/10.4000/variants.391

This text was automatically generated on 25 September 2020.

The authors 


\title{
Ivo Castro, Editar Pessoa
}

\author{
Simone Celani
}

\section{REFERENCES}

Ivo Castro. Editar Pessoa. $2^{\text {nd }}$ ed. Lisboa: Imprensa Nacional — Casa da Moeda, Lisboa, 2013. $384 \mathrm{pp}$.

1 Twenty-five years ago, a national project began for the publication of the critical edition of Fernando Pessoa's works, commonly known as the Equipa Pessoa. Two works inaugurated the project: the critical edition of the poems of Álvaro de Campos, edited by Cleonice Berardinelli, and a volume which was to serve as the introduction to the entire project, a collection of essays by the coordinator of the Equipa, Ivo Castro. In 2013, over two decades later and after the publication of numerous volumes, a new edition of the latter book - greatly expanded and updated - was published. The original volume contained nine essays, divided into two sections. Eight of these have been republished in the new edition, along with seventeen additional, more or less recent contributions all of which but one had been previously published, in a scattered fashion, in various magazines and books. The essays of the first edition dealt mainly with the initial Equipa project and the editorial model adopted (in the first part of the volume), as well as the preparation of the critical edition of $O$ Guardador de Rebanhos by Alberto Caeiro (in the second part). The latter subject matter in particular was included in the first, larger section of the book, entitled Poesia de Pessoa: editar e ler, which has been supplemented by material of various origin but continues for the most part to be prevalently dedicated to methodological considerations connected to the work on Guardador. The additional contributions, however, broaden the field in the direction of increasingly more general considerations of greater methodological interest, not exclusively Pessoan. At the same time, the essays belonging to the first part of the original edition have been included in the second section of the book, entitled simply Equipa Pessoa and also supplemented by new contributions which enlarge on the original themes. The third part, Polêmicas pessoanas, is on the other hand completely new and contains two essays written collaboratively by 
several authors. The first deals with the controversy arising in Italy from the publication of Eliezer, an alleged novel by Pessoa which subsequently turned out to be simply a translation in English of a text by someone else, while the second essay deals with the controversy deriving from the publication of the above-mentioned critical edition of the poems of Álvaro de Campos. Despite the division into sections, the book is very cohesive and the more important issues reappear in different parts of the volume. In this sense, it is possible to read the book as a single unified manual of Pessoan philology - despite being filtered through essays written at different times and not always completely organic - and at the same time as a kind of stock-taking of the work of the Equipa and, more generally, of the last twenty-five years of critical editions of Pessoa's work. Within the former perspective can be read in particular the contributions that contain indications on the process of putting together the editions or on the critical results that can be obtained with the application of a rigorous ecdotic method (as shown in the pages dedicated to the documents revealing the true facts behind the myth of the dia triunfal, the triumphal day). Essays like "Para uma edição de O Guardador de Rebanhos [O G. de R.]", "O corpus de O G. de R"., "O manuscrito de O G. de R.", "A edição crítica de O G. de R.", "A casa a meio do outeiro" e "Modelo editorial adoptado", along with the "Metodologia do aparato genético", "Verdades pessoanas", "Filologia pessoana" and "From Print to Script", furnish sufficient examples and considerations for a very clear idea of the difficulties involved in the work on the Pessoa papers and of the method to be followed in order to produce reliable editions. The method is founded in particular on the model of French genetic criticism and on the textual criticism of the North American school, but is also open to suggestions from Italian critica delle varianti. The modus operandi is based on a careful study of the originals, aimed at reconstructing the chronology of the textual variants present in the manuscripts and based on choice of the last in chronological order as the variant to be included in the established text. The decision proceeds from theoretical premises, but it also relies on a statistical study of the decisions effectively taken by the author in the (relatively few) cases in which he managed to publish his writing during his lifetime. Such a model does present one weakness, in my opinion, which lies in the editorial treatment of the alternative variants, which are placed in appendices alongside all the other typologies. I still believe, following Dante Isella, as well as Giuseppe Tavani, that a separate position, of greater importance, would in this case have been desirable, given that the alternative variants offer considerable value in that they foster textual "openness", or an "unravelling" of the text itself. I do not believe that it is true, as Ivo Castro claims, that we can always rely on "derradeira lição em relação à qual o autor não teve dúvidas transmitidas ao papel" (99) ("the last lesson in which the author left no evidence of doubt on the paper"), because, in the case of the alternative variants, the failure to eliminate the prior variant is an evident sign of doubt. This would also help to give emphasis to the critical worth of the editions in comparison with their purely genetical value. Turning to the assessment of the last quarter century of ecdotic studies applied to Pessoa, today's re-reading of the essays already published in the first edition of the book, such as the Projecto inicial of 1988, makes it possible to easily compare aims and actual achievements. On p. 157 in particular there is a brief fivepoint list which represents the ambitious initial mission of the Equipa: it should be said that, while most of the aims have been achieved, two in particular and of no small importance have been disregarded: the publication of all the support tools used in the study of the Papers - "inventários, catálogos de documentos datados, concordâncias 
lexicais, etc" ("inventories, catalogues of dated documents, lexical concordances, etc".) - and the publication of a series of popularizing editions, in order to fulfil the need for the new versions of Pessoa's work to reach the general public (this project came to a standstill with the first and only published volume). In this direction, the use of new computer tools and the preparation of digital editions, suggested more than once by Castro himself, could in the future represent a useful compromise solution between documentary completeness, synoptic interpretation of the various textual stages and accessibility. Apart from this, as is clearly evident to those who have eyes to see, the results do not after all fall so far short of the aims, thanks to the publication of critical editions of almost the entire poetic production, to which have been added important editions taken from the great mass of prose writing: in particular the Livro do Desasocego, the works of António Mora and the reflections relating to Sensacionismo $e$ outros ismos. Objective problems not related to the work of the Equipa have, however, recently led to a slow-down in the work, in particular the discovery of the existence of the so-called Espólio II, dealt with partially or completely by several of the more recent essays in the book, such as Decifrar Pessoa, From Print to Script and A classificação do Espólio Pessoa como bem de interesse nacional, as well as an essay of overall synthesis, which also constitutes a passionate defence of the role of libraries, entitled A casa fechada. The recent discovery of original material by Pessoa still in the hands of the family which had never been handed over to the Biblioteca Nacional of Lisbon, despite the agreement stipulated when the archive was sold to the Portuguese State, and the even more objectionable decision to auction them off have marked a deep and partly irreparable fracture in the history of Pessoan studies. A situation almost unique in the field of ecdotics of a contemporary manuscript where it was presumed that the author's material in its entirety was collected in a public institution and made available to scholars has instead turned into a situation of dispersion, without doubt relating to a minor portion of the papers (about 2000 documents out of the c. 27,000 held in the Biblioteca Nacional collection) but which are nevertheless of scholarly importance. The belated definition of the archive as a national treasure, which occurred in 2009, accompanied by the prohibition of taking any material which could be related to Pessoa out of the country, failed to resolve the issue, which continues to have its obscure points and above all casts doubt on the completeness of any genetic dossier present in past or future editions. In the face of this situation the Pessoan controversies referred to in the last part of the volume, rich as they are with precious methodological teachings and sharp ecdotic skirmishes, can now be read, almost nostalgically, as testimony to a past time when the author's manuscripts could create even strong disagreements, but were always functional to the overall increase of knowledge. In conclusion, the new edition of Editar Pessoa offers a necessary and useful update, and a work which, despite its partially fragmentary and repetitive nature (defects which could have been avoided by carrying out a task of harmonization and re-organization, aimed at a more cohesive and complete text), contains the essence of broad scientific knowledge, technique and methodology, filtered through constant and prolonged contact with the original papers, a contact that represents the one and only premise for any attempt to approach that incredible and complex legacy of human knowledge which is the work of Fernando Pessoa. 


\section{AUTHORS}

\section{SIMONE CELANI}

Simone Celani is Associate Professor of Portuguese Studies at the University of Rome "La Sapienza". Among other things, he worked on Portuguese Philology (Fernando Pessoa, José Cardoso Pires, António Vieira), grammatical treatises of the Sixteenth Century, African Literature, Translation Studies. 